\title{
Leaf Water Potentials of Perennial Grasses-Leaf Press and Pressure Chamber Evaluation
}

\author{
JERRY R. COX AND H. GLENN HUGHES
}

\begin{abstract}
The leaf water potentials of blue grama [Bouteloua gracilis (H.B.K.) Griffiths] and western wheatgrass (Agropyron smithii Rydb.) transplants were measured using a pressure chamber and a leaf press. Combined water potentials for both species ranged from $\mathbf{- 5 . 3 4}$ to $\mathbf{- 2 6 . 0 5}$ bars for the pressure chamber and $\mathbf{- 5 . 5 2}$ to -16.24 bars for the leaf press. Trends between the to methods were more consistent for blue grama. Generally, large increases in leaf water potential measured with the pressure chamber were measured as small changes with the leaf press.
\end{abstract}

The pressure chamber (pressure bomb) originally described by Dixon (1914) and later re-introduced by Scholander et al. (1964) is a widely accepted method for determining leaf water potential of crops and range plants. Field measurements with the pressure chamber are easily obtained (Waring and Cleary 1967) but the compressed gas canister is bulky, hard to handle and presents a safety hazard.

To alleviate the potential safety hazards Campbell Scientific has modified a standard 1 ton hydraulic jack (J-14 Leaf Press) to measure plant water potential. The leaf press ${ }^{1}$ is easily handled, rugged, and field measurements can be made quickly. However, the leaf water potential measurement may not be quantitative. Brown et al. (1975) compared the leaf press and a thermocouple psychrometer using leaves with petioles, leaflets, and leaf disks of various shrubs and forbs. They found little correlation and concluded that leaf water potential measurements with the leaf press were not a reliable measure.

Campbell Scientific (1974) states that three possible end points for shrubs and trees may be observed with the leaf press: (1) the cut end of the leaf exudes a small moisture bubble; (2) the leaf darkens and more moisture can be seen at the cut edge; and (3) the leaf turns black with moisture exuded at both cut and uncut edges. The importance of the first end point has not been established but possibly may be related to night-time pressure chamber observations. The second end point seems to correlate with day-time pressure chamber observations. The third end point may be related to osmotic or possibly matric water potentials (Shayo-Ngowi and Campbell 1980).

References comparing the pressure chamber and the three end points of the leaf press are unavailable for range grasses. The purpose of this study was to compare the pressure chamber, as the standard, and the leaf press on greenhouse plants to determine if leaf water potential measurements for the two methods were similar and to assess the reliability of the leaf press.

\footnotetext{
Authors are range scientist, Agricultural Research, Science and Education Administration, 2000 East Allen Road, Tucson, Arizona 85719; and research assistadministration, 2000 East Allen Road, Tucson, Arizona 85719; and research assist78801. At the time of the study the authors were research associate and research assistant, respectively, Range Management Division, University of Wyoming, Laramie.

Manuscript received April 11, 1980.

'Use of trade names is for the reader information only and does not imply endorsement of commercial products by the United States Government or the Texas Agricultural Experiment Station System.
}

\section{Methods and Materials}

\section{Description of the Leaf Press}

The leaf press was constructed by removing the plunger from a 1-ton hydraulic jack and welding an aluminum head and pressure gauge to the exterior frame of the jack (Fig. 1). The head has a fixed lower half with three locking bolts, a neoprene membrane to confine hydraulic fluid, and a nylon covering for detecting moisture and tissue color changes. A removable cap, with plexiglass for viewing color changes, locks over the bolts and pressure is applied by depressing the jack handle.

\section{Greenhouse Procedure}

Four mature adult plants each of blue grama $[$ Bouteloua gracilis (H.B.K.) Griffiths] and western wheatgrass (Agropyron smithii Rydb.) were transplanted from the field to a greenhouse in August, 1976. Blue grama was grown at 21 to $26^{\circ} \mathrm{C}$ with relative humidity of 40 to $60 \%$; western wheatgrass was grown at 11 to $17^{\circ} \mathrm{C}$ with

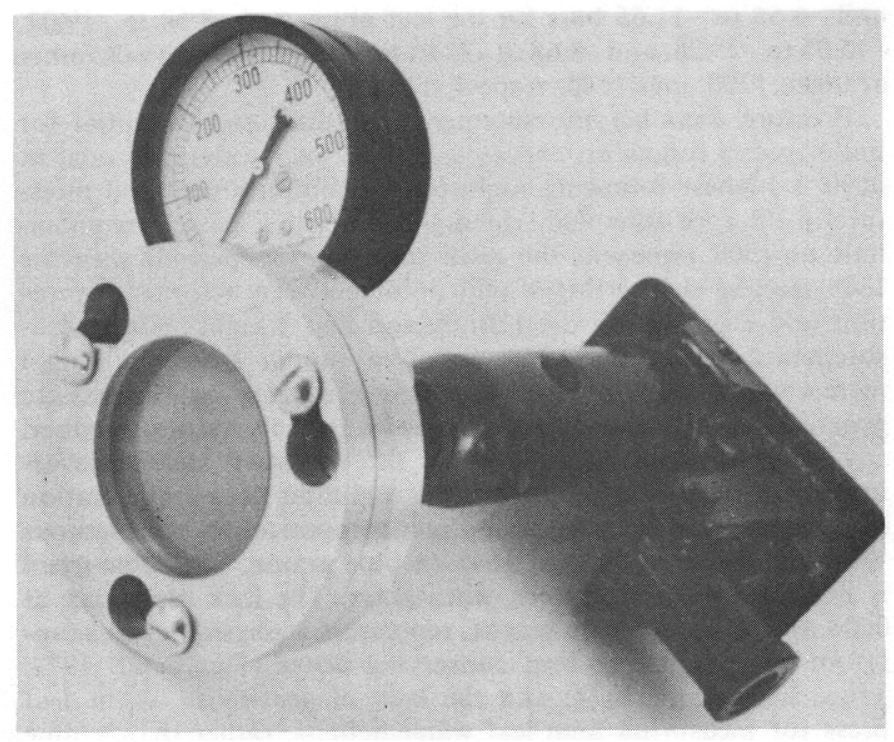

Fig. 1. Campbell Scientific Model J-14 hydraulic press.

humidity of 30 to $50 \%$. These are optimum growing conditions for the respective species.

The tests began on December 23, 1976, by watering each plant, covering the soil with perlite, and wrapping each pot in plastic to reduce evaporation. Forty-eight hours later we began sampling, and continued for 8 days, at 0600,1200 and 1645 (sunrise was at 0730 and sunset at 1600). On the third day of the experiment, the perlite and plastic were removed to increase evaporation. Three pairs of similar leaves were removed, two leaves at a time, from each plant at each sampling period. One leaf was placed in the pressure chamber, the other was placed in the leaf press. 
Table I. Mean leaf water potentials and standard errors (-bars) of greenhouse grown blue grama and western wheatgrass for the leaf-press and pressure chamber at three times of the day.

\begin{tabular}{|c|c|c|c|c|c|c|}
\hline \multirow[b]{2}{*}{ Species } & \multicolumn{2}{|c|}{0600} & \multicolumn{2}{|c|}{1200} & \multicolumn{2}{|c|}{1645} \\
\hline & Leaf-press ${ }^{1}$ & Pressure chamber & Leaf-press & Pressure chamber & Leaf-press & Pressure chamber \\
\hline Blue grama & $7.79^{c} \pm 1.22$ & $8.64^{c} \pm 2.09$ & $11.25^{b c} \pm 1.22$ & $16.83^{b} \pm 1.80$ & $11.12^{\mathrm{bc}} \pm 1.09$ & $15.52^{b} \pm 2.34$ \\
\hline Western wheatgrass & $7.43^{c} \pm 1.19$ & $13.40^{b} \pm 2.02$ & $9.6 T^{c} \pm 0.88$ & $21.18^{n} \pm 1.98$ & $9.00^{c} \pm 1.53$ & $15.50^{b} \pm 2.30$ \\
\hline
\end{tabular}

Means with different superscripts are significantly different at $5 \%$ level.

Because of difference in chamber sizes, $10-$ to 20 -cm leaf segments were used in the pressure chamber and $5-\mathrm{cm}$ leaf segments in the leaf press. Leaves were inserted into the pressure chamber with a $2.54 \mathrm{~cm}$ of the cut base remaining above the retaining lip. Pressure was applied at the rate of $0.7 \mathrm{~kg} / \mathrm{cm}^{2} / \mathrm{sec}$, and when moisture was exuded from the cut edge the pressure was recorded. After the cut leaf was inserted into the leaf press and the cap locked, pressure was increased at the rate of $0.5 \mathrm{~kg} / \mathrm{cm}^{2} / \mathrm{sec}$ and the pressure at each end point recorded. However, as water stress increased, the second and third end points were not always evident. The first end point, when water was initially exuded from the cut leaf edge, was always detectable. Pressure chamber and leaf press measurements were summarized over 8 days, by species and sampling time, with multiple mean comparisons, standard errors, and regression coefficients.

\section{Results and Discussion}

Leaf press measurements for blue grama varied from -5.98 to $-10.11,-10.23$ to -12.72 , and -8.94 to -16.24 bars over the 8 days at 0600,1200 , and 1645, respectively. Pressure chamber measurements for the three times were -5.34 to $-17.54,-11.81$ to -24.82 , and -10.23 to -26.05 bars, respectively. Measurements for western whcatgrass varied from -5.52 to $-10.43,-7.93$ to -11.38 , and -6.55 to -11.55 bars for the leaf press; and -8.68 to -19.02 , -15.05 to -25.28 , and -8.68 to -25.01 bars for the pressure chamber at 0600,1200 , and 1645 , respectively.

Pressure chamber measurements of leaf water potential for both species follow an expected pattern: leaf water potential at 0600 is highest following night-time equilibration of soil moisture in the root zone and stomata closure; low leaf water potentials at 1200 represent the peak transpiration period, with the 1645 reading delineating a mid point between active transpiration and stomata closure (Hutcheson and Knight 1974). Measurements for the leaf press follow a similar trend, but small increases observed for the leaf press in periods of water stress are generally measured as large increases with the pressure chamber.

Comparisons on blue grama for the two water stress measuring apparatuses were similar before and after peak transpiration (Table 1). The data suggest a direct comparison of the methods would be useful at 0600 or 1645 on blue grama. The same trend is not apparent for western wheatgrass. The lack of change at 0600 and 1645, for blue grama, represents a physiological adaptation for fixing $\mathrm{CO}_{2}$ and conserving water (Dye et al. 1972, Trlica and Singh 1974) and the lack of sensitivity of the leaf press for measuring high leaf water deficits, rather than a time when the two methods can be directly compared.

Leaf water potentials for the two methods are poorly correlated for both species, with the exception of the predawn measurements for blue grama (Table 2). Hutcheson and Knight (1974) measured the diurnal and seasonal trends of water potential for blue grama with a thermocouple psychrometer. Under ideal growing conditions predawn measurements are comparable with our observations with both the leaf press and the pressure chamber, while the 1200 and 1645 observations are comparable only with the pressure chamber.

Differences in leaf water potential estimates for the two methods are dependent on the atmosphere surrounding the leaf as pressure increases. The complete leaf is enclosed in the leaf press and pressure is equal on all vegetative material. The atmos-
Table 2. Regression coefficients (r) comparing leaf water potentials, obtained by two methods, for blue grama and western wheatgrass.

\begin{tabular}{llll}
\hline & \multicolumn{3}{c}{ Time } \\
\cline { 2 - 4 } Species & 0600 & 1200 & 1645 \\
\hline Blue grama & 0.62 & 0.34 & 0.14 \\
Western & 0.25 & 0.07 & 0.33 \\
$\quad$ wheatgrass & & & \\
\hline
\end{tabular}

phere within the pressure chamber is equal on the leaf within the chamber, but a rubber retaining cork, which holds the leaf in place, allows water to be forced out the cut edge of the leaf into a different atmosphere. At higher pressure readings the retaining cork may restrict water flow by acting as a pincher on the leaf. Therefore, the pressure chamber may over-estimate internal leaf water deficits.

\section{Conclusions}

The leaf press has logistical and safety advantages over the pressure chamber. Predawn measurements with the leaf press are generally equivalent to similar predawn collections with the pressure chamber if soil moisture and temperature are optimum. Comparisons are erratic during periods of water stress, and large increases in leaf water potential measured with the pressure chamber are measured as small changes with the leaf press.

The leaf press may be used to estimate predawn water potentials of herbaceous species under ideal growing conditions when a general trend is adequate. The leaf press is not recommended for accurate water stress determinations on range grasses at peak transpiration nor for predawn estimates when soil moisture is limiting.

\section{Literature Cited}

Boyer, J.S. 1967. Leaf water potentials measured with pressure chamber. Plant Physiol. 42:133-137.

Brown, R.W., W.T. McDonough, and L. Van Kekerix. 1975. Comparison of the thermocouple psychrometer and leaf press for measuring leaf weather potential. Northwest Sci. Meeting, Pap. No. 115.

Campbell Scientific. 1974. Instruction manual - Model J-14 Press. Campbell Scientific, Inc., Logan, Utah. 8 p.

Dixon, H.H. 1914. Transpiration and the ascent of sap in plants. The Macmillan Co. New York.

Dye, A.J., L.F. Brown, and M.J. Trlica. 1972. Carbon dioxide exchange of blue grama as influenced by several ecological parameters. US/IBP Grassland Biome Tech. Rep. 181. Colorado State Univ. Fort Collins. 32 p.

Hutcheson, J.L., and D.H. Knight. 1974, Response patterns of blue grama leaf water potential, measured with a thermocouple psychrometer. IBP. Tech. Rep. 241.58 p.

Scholander, P.F., H.H. Hammel, E.A. Hemmingsen, E.D. Bradstreet. 1964. Hydrostatic pressure and osmotic potential in leaves of man groves and some other plants. Proc. Nat. Acad. Sci. 52:119-125.

Shayo-Ngowi, A., G.S. Campbell. 1980. Measurement of matric potential in plant tissue with a hydraulic press. Agron. J. 72:567-568.

Trlica, M.J., and J.S. Singh. 1974. Translocation of assimilates and creation, distribution and utilization of reserves. $m$ : IBP Arid-Lands Synthesis, Cambridge University Press. Cambridge. 76 p.

Waring, R.H., and B.D. Cleary. 1967. Plant moisture stress: Evaluation by pressure bomb. Science. 155:1253-1254. 